\title{
Ембриология на структурите на носната преграда
}

\section{(Литературен обзор)}

\author{
Пл. Недев \\ Клиника по УНГ-болести при МБАЛ "Св. Марина" - Варна \\ Катедра по неврохирургия, оториноларингология и офталмология при \\ Медицински университет - Варна
}

\begin{abstract}
The development of the nose cavity begins in 32 days embryos, with the dimension of $5 \mathrm{~mm}$.

This paper presents an embryological survey of the development of the nasal cavity, the nasal bones and cartilages. We examine in details the nasal cavity structure's anatomy in order to facilitate the surgical procedures. The description is focused on specific sections that are important for a more complete understanding of various biological and functional aspects of the nasal cavity.
\end{abstract}

\section{Резюме}

Развитието на носната кухина започва още при 32-дневни ембриони с обща големина от 5 мм. В статията са представени ембриологични данни за развитието на носната кухина и изграждащите я хрущяли и кости. Подробно са разгледани анатомичните особености на структурите на носната преграда за целите на оперативните интервенции на носната преграда. Описват се важни във функционално и анатомично отношение отдели на носната кухина.
$\mathrm{P}$ азвитието на носната кухина започва още при 32-дневни ембриони с обща големина от 5 мм с едно задебеление на ектодермата в областта на челния апофиз, който се означава като главна плакода. Placoda nasalis ce спуска бързо към Fovea nasalis, a след това към Saccus nasalis и отделя от челно-назалния израстък (Promenentia frontonasalis) една промененция Promenentia nasalis medialis от Promenentia nasalis lateralis.

След нейното разтваряне при ембриони с 15 мм дължина се образува първичната носна кухина и Choana primitiva. Секундарната носна кухина възниква чрез отделяне на част от Stomatodeum (примитивна устна кухина), която затваря носната кухина. Относително дебелият носен септум нази и неговият прехрущял и хрущял при 19 мм ембриони расте надолу едновременно с горночелюстните апофизи двустранно на черепния апофиз. При 18-20 мм ембриони езикът се разполага между proc. palatini. При 35 мм ембриони започват processus palatini да се сливат с първичния череп отпред назад (Peter 1913, Diwert 1983). След това сливане на двете черепни части и с долната септума след това епителни клъбца, които по-късно се резорбират. Дорзалната част на стоматодеум не се разделя на два етажа, а образува фаринкс. Чрез развитие, повдигане и сливане на черепните части една с друга със септума се образува и саvum nasi от отрязък на stomatodeum.

При 7-8 седмични ембриони възникват хрущялните части на външния и вътрешния нос, първо в областта на septum nasi, а след това се оформят носните латерални стени - долна носна конха в осма ембрионална седмица, средна в девета и горна в дванадесета. 
Отпред и отдолу на cartilago septi ce оформят парасепталните хрущяли на Jacobson. Към края на трети ембрионален месец се оформя носната клапа. Ембриологичното развитие на носа започва около третата фетална седмица. Сензорният епител се образува в едно задебеляване на краниалната ектодерма и задължително става, формира чифтна носна или олфакторни плакоди, които се локализират от двете страни на фронталната промененция, точно над стомодеум. По време на петата седмица се появяват латерални и медиални носни подувания като гънки около носните плакоди, като последните тогава стават хлътнали и образуват носните отвори (Moore 1973). В дълбочина тези носни отвори се отделят от фронтоназалния процесус на медиални и латерални компоненти, като се сформира едно сливане, което е примитивният назален септум. По-отдолу има чифтен максиларен процесус, който се отделя от първа брахеална арка, за да се слее с медиалния назален процесус.

По време на шестата седмица цепковидните и покрити с епител носни отвори започват да вървят назад, като така образуват тьнка буконазална мембрана, която отделя носната от устната кухина. После тази мембрана руптурира и образува ранните хоани, които се разполагат по-назад вследствие на палатинното развитие.

Палатинното нарастване се комбинира с руптура на буко-назалната мембрана, за да улесни развитието на окончателния назален септум, който расте едновременно назад към сфеноидалния процесус. През третия фетален месец става мезенхимно струпване и хрущялът нараства към сфеноида, за да образува двете допълнителни пластинки, които се сливат не само една с друга, но също така и вентрално с латералните носни стени, за да образуват носната капсула. По време на шестия фетален месец врастването (растежът навътре) на свързващите тъкани разделя капсулата на горен и долен латерални хрущяли, а така също и на септален хрушял.

\section{Литература:}

1. Lang J. Kliniche Anatomie der Nase, Nasenholen und Nebenholen: Grundlagen fur Diagnostik und Operation. 1988, Stuttdart; New York: Thieme.1-134.

2. Kim, Chang-Hoon MD; Park, Hyoung Woo MD; Kim, Kyubo MD; Yoon, Joo-Heon MD Early Development of the Nose in Human Embryos: A Stereomicroscopic and Histologic Analysis. Laryngoscope. 2004114(10): 1791-1800.

3. Shone G.R., et al., Mucociliary function in the early weeks after nasal surgery., Rhinology., 1990, 28, 265-268.

4. Broms P., Jonson B., Malm L.: A pre-and post-operative evalution in functional septoplasty. Acta oto-laryngol., 1982, 94, 523.
Задната част на хрущялната капсула започва да осифицира и да замества хрущяла с кост в средата на пети фетален месец. Този процес продължава до възрастен човек.

Частта на перпендикулярната пластинка, която по-късно формира крибриформената пластинка, остава фиброзна до третата година, когато осифицира и така стабилизира етмоидалния комплекс. Напред Lamina perpendicularis може да достигне до назалната спина на фронталната кост или може и по-далеч - до края на носните кости.

Vomer не се развива чрез осификация на хрущяла, а от съединителни тъкани, които съществуват от двете страни на септалния хрущял. Хрущялът между ламелите на vomer ce абсорбира и по този начин разрешава сливането на вомералните пластинки. Тези пластинки растат нагоре, за да се срещнат с перпендикуларната пластинка на етмоидалната кост и задната част на септалния хрущял във вдлъбнатината на цялостните пластинки на vomer. По данни на Broman (1911) (цит. по Lang 1989) в 7-8 ма ембрионална седмица започва развитието (оформянето) на септалния хрущял. В края на втория ембрионален месец носната капсула е цялостно превърната в хрущял. Vomer се развива (оформя) в третия ембрионален месец въз основа на осификации под формата на две костни ламели, които се съединяват една с друга. Нагоре ламелите се отдръпват V-образно една от друга. В този жлеб отпред заляга хрущялът на септума. Назад двете ламели, вече като Alae vomeris, обхващат Rostrum sphenoidalis. По-късно се удължава долната част на vomer. Според Zuckerkandl (1892) и Lang (1989) хондралната осификация на Lamina perpendicularis започва в шестия месец от живота от областта на Crista gallii и върви отгоре и надолу. Същите резултати дават Schultz-Coulon и Eckermeyer (1976) (цит. по Lang 1989). Shone (1990) приема, че за развитието и израстването на носа от решаващо значение е септумът.

B третата година от живота осификацията на Lam. perpendicularis и Vomer вече е достигната.

5. Tolemalm N.: Aerodinamics and mucociliary function of upper airways., Eur. Respir. Dis., 1985,vol. 66, Suppl. 139, 55-56.

6. Bruintjes Tj. D., A.F. van Olphen, B. Hillen. Revew of the functional anatomy of the cartilages and muscles of the nose. Rhinology, 1996, vol $34,2,66-75$.

7. Haapaniemi JJ. et al., Prevalence of septal deviations in school aged children., Rhinology. 1995, 33, 1, 1-3.

8. Session B.R., Weing L.B.: The nasal septum. Otolaryngology Head and Neck Surgery. 1989, Vol.1 637-696

9. Moore K.L.: The developing human, Philadelphia, 1973, W.B. Saunders Co. 